\title{
Length-weight relationship and condition factor of Mugil cephalus and Oreochromis niloticus from a Tidal creek in the Niger Delta, Nigeria
}

\author{
M. Moslen ${ }^{1 *}$ and C.A. Miebaka ${ }^{2}$ \\ ${ }^{1}$ Department of Animal and Environmental Biology, Rivers State University, Port Harcourt, NIGERIA \\ ${ }^{2}$ Institute of pollution studies, Rivers State University, Port Harcourt, NIGERIA \\ *Corresponding author's E-mail: moslen4c@yahoo.com
}

\section{ARTICLE HISTORY}

Received: 10 November 2017

Revised received: 20 November 2017

Accepted: 26 November 2017

\section{Keywords}

Condition factor

Fish

Length-weight

Niger Delta

Tidal creek

\begin{abstract}
The aim of this study was to assess the length-weight relationship (LWR) and condition factor (K) of Mugil cephalus and Oreochromis niloticus obtained from a tidal creek in the Niger Delta Nigeria. Six samples of each species were randomly collected monthly (January - December 2015) from fisher men making a total of 144 samples. Samples were immediately taken to the laboratory in ice pack coolers for analysis. The b-values ranged from 0.913-3.172 and 1.624-3.484 while K-values ranged from 0.79-1.07 and 1.01-1.08 for M. cephalus and O. niloticus respectively. The results indicated positive and negative allometric growth patterns $(b>3 \& b<3)$ for the two fish species, a departure from the cub law, but $M$. cephalus exhibited isometric growth pattern $(\mathrm{b}=3.003)$ during just one month of the study period, a compliance with the cube law. Growth coefficient also had obvious inter and intra specific variation while condition factor did not but indicated wellbeing of fish samples examined. The weight of both fish showed significant difference $(P<0.01 / P \leq 0.05)$ with respect to time while $\mathrm{R}^{2}$ values indicated strong linear relationship between length and weight. The study concluded that allometric growth pattern observed for the two fish species had both inter and intra specific variation along temporal lines. However, inter and intra specific condition of fish examined was relatively stable across study period suggesting the two different species could have responded to ecological and environmental variables similarly.
\end{abstract}

(C2017 Agriculture and Environmental Science Academy

Citation of this article: Moslen, M. and Miebaka, C.A. (2017). Length-weight relationship and condition factor of Mugil cephalus and Oreochromis niloticus from a Tidal creek in the Niger Delta, Nigeria. Archives of Agriculture and Environmental Science, 2(4): 287-292, DOI: $10.26832 / 24566632.2017 .020406$

\section{INTRODUCTION}

Evaluation of length-weight relationship (LWR) remains a veritable aspect of fish biology. LWR used in combination with fish condition factor has become very useful in aquaculture. According to Silva et al. (2015), mathematical models of fish growth give an objective and practical method for describing patterns of growth data and estimating fish weight at times between sampling intervals. Accurate estimations of standing biomass, and therefore, of the amount of feed that must be provided, are vital to aquaculture management. Pauly (1993) reported that length-weight relationships can be used to predict weight from length measurements made in yield assessments while Lizama et al. (2002) stated that knowledge of quantitative aspects such as length-weight relationship, condition factor, growth, recruitment, and mortality of fishes are important tools for understanding fish biology The condition of a fish has been said to reflect recent physical and biological circumstances, due to strong influence by both biotic and abiotic environmental variables, and changes by interaction among feeding habits, parasitic burden and fish physiological conditions (Le Cren, 1951; Olurin and Aderibigbe, 2006). The condition factor in fish also serves as a measure of the physiological state of fishes in relation to their welfare (Le Cren, 1951; Ighwela et al. (2011) and provides information when comparing two populations living in certain feeding density, climate and other conditions (Weatherly and Gills, 1987).) But, fish might show different growth patterns (isometric and allometric) due to water quality, nutrition, habitat, density, sex and time of life stages (Ali et al., 2000). Thus length-weight relationship and condition factor are important parameters for assessing the health condition (Nehemia et al., 2012; Mortuza and Al-Misned, 2013) and also important for understanding the life cycle of fish species and contributes to adequate management of these species and, therefore, to the maintenance of equilibrium in the ecosystem (Lizama et al., 2002). Fish with negative allometric growth, are associated with poor condition, which suggests that the fish becomes more slender as it increases in weight while fishes with appropriate condition factor have isometric growth, which implies that the fish becomes relatively deeper-bodied as it increases in length (Migiro et al., 2014). The condition factor of fish can also be affected by a number of factors such as stress, sex, season, availability of feeds, and other water quality parameters (Khallaf et al., 2003). Hence the condition of a particular 
fish is strongly related to the length and weight of the fish vis-à-vis prevailing environmental factors. Condition factor compares both inter- and intra- specific "condition", "fatness" or wellbeing of fish from the same or contrasting habitats and a useful index for monitoring of feeding intensity, age and growth rates in fish (Oni et al., 1983), which can then be used to assess the quality of the aquatic habitat of the fish. Tilapia (Oreochromis niloticus) and mullets (Mugil cephalus) are fish of very high economic and commercial value within the Niger Delta and beyond. Such fish are good source of proteins and vitamins and attracts high exploitation due to demand. The aim of this study was to examine the length weight relationship and condition factor of two fish (Oreochromis niloticus and Mugil cephalus) obtained from the same estuarine creek (Azuabie) in the Niger Delta and compare intra and inter specific condition of the fish samples.

\section{MATERIALS AND METHODS}

Study area: The study area is an estuarine creek (Azuabie creek) in the upper reaches of the Bonny estuary in the Niger Delta, Nigeria (Figure 1). The creek has rich fishery resource and is habitat to Tilapia and Mullets, however, impact of human activities is becoming a serious threat the fishery resources of the area. The study area is located on the eastern flank of Port Harcourt city and catches from this area greatly compliments protein demands of city dwellers.

Collection of fish samples: Fresh samples were collected directly from the fishermen on a monthly basis for twelve months (January to December 2015). Six samples were collected for each species of fish per month making a total of 144 samples during the study. The samples were immediately transported in ice pack coolers to the laboratory for analysis.

Laboratory analysis: Excess water from fish body was removed using filter paper before weighing to ensure accuracy (Anderson and Gutreuter, 1985). Total length and weight of fish samples were measured to the nearest $0.1 \mathrm{~cm}$ and $0.1 \mathrm{~g}$, respectively. Calibrated meter rule was used to measure fish length while weight of sample was determined with an electronic weighing balance (model- P1203).

Length-weight relationship and condition factor: The Length-Weight relationship was evaluated using the equation $\mathrm{W}=\mathrm{aL}^{\mathrm{b}}$ (Pauly, 1983). Where $\mathrm{W}=$ Fish weight $(\mathrm{g}), \mathrm{L}=$ Fish length $(\mathrm{cm}), \mathrm{a}=$ intercept (rate of change of weight with length), $b=$ slope (weight at unit length). Log-transforming the equation $(\log a+b \log L=\log$ weight $+b \log$ Length) was done to determine ' $a$ ' and ' $b$ '. If " $b$ " $=3$ then growth is isometric, if not the growth is allometric $(>3=$ positive allometric growth, $<3$ = negative allometric growth).

The condition factor of the fish was evaluated from the mean weight and length of the six replicate specimens using the equation, $\mathrm{K}=\mathrm{W} / \mathrm{aL}^{\mathrm{b}}$

Where by $\mathrm{K}=$ condition factor; $\mathrm{W}=$ fish weight $(\mathrm{g})$; $\mathrm{L}=$ Fish total length $(\mathrm{cm}) ; \mathrm{b}=$ the value obtained from the lengthweight equation.

The exponent ' $b$ ' value that is equal to 3 was not used to calculate the ' $\mathrm{K}$ ' value because Bolger and Connolly (1989) had stated that it is not a real representation of the lengthweight relationship for greater majority of fish species, hence the ' $b$ ' value was obtained from the estimated length-weight relationship equation $\left(\mathrm{W}=\mathrm{a} \mathrm{L}^{\mathrm{b}}\right)$ as suggested by Lima-Junior et al. (2002). The length-weight relationship and condition factor were calculated irrespective of fish sexes and size.

Statistical analysis: Analysis of variance (ANOVA) using
General linear model was applied to $\log (x+1)$ transformed length and weight data to detect temporal significant differences. Tukey test was used for mean separation while tTest was used to determine significant difference between coefficient of growth as well as condition factor between the two fish species examined. Ms Excel and Minitab 16 were the software packages used.

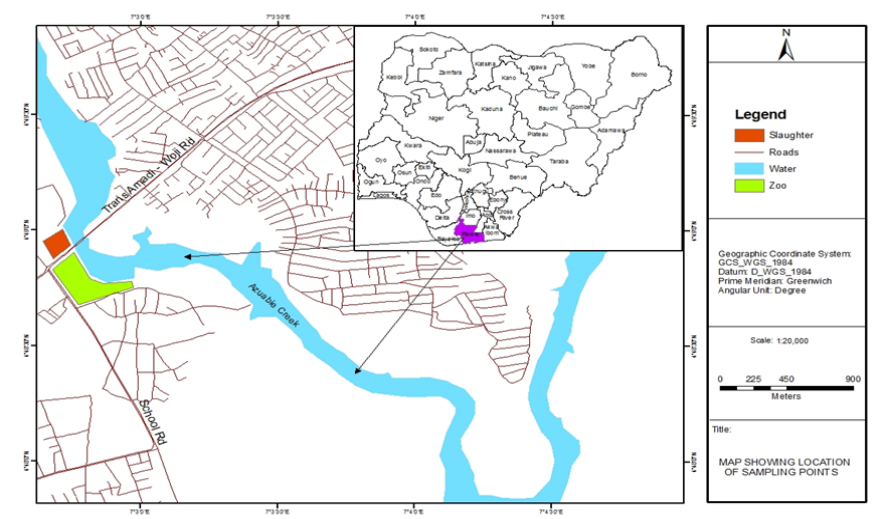

Figure 1. Study site where fish samples were collected (C IOSR 2017).

\section{RESULTS AND DISCUSSION}

The regression of weight on length of fish samples examined on a temporal basis is given in Figures 2 and 3 for Mugil cephalus and Oreochromis niloticus, respectively. Temporal trends of $\mathrm{b}$ and $\mathrm{K}$-values for both fish is also shown in Fig. 4 while the ANOVA extract with $\mathrm{F}$ and $\mathrm{P}$-values is given on Table 1. The growth coefficient (b-value) for M. cephalus ranged from 0.913 in September to 3.172 in July showing isometric, positive and negative allometric growth patterns. The b-value for $O$. niloticus ranged from 1.624 in August to 3.484 in February indicating positive and negative allometric growth styles. The b-values for both fish showed temporal variations while the $\mathrm{K}$-values of the fish showed relative stability across the period of study and indicated that both fish were in good condition. Analysis of variance (ANOVA) for weight values of $M$. cephalus was significantly different $(P<0.01)$ while those of length was not $(P>0.05)$ across the period of the study. Post hoc analysis using Tukey test showed that the significance difference in weight occurred thus: January $>$ August $=$ February $=$ November $=$ December $=$ October $=$ September $=$ May $=$ April $=$ March $>$ July $=$ June. Similarly ANOVA for the weight values of $O$. niloticus showed significant difference $(\mathrm{p} \leq 0.05)$ while those of length did not $(P>0.05)$ but pair wise comparison could not detect where actual difference occurred for weight of $O$. niloticus. Comparison of $\mathrm{b}$-values of both fish using $\mathrm{t}$-Test showed no significant difference $(P>0.05)$ likewise for $\mathrm{K}$-values of both species. The LWR for the two fish species examined was linear and also strongly related as indicated by the $\mathrm{R}^{2}$ values in the regression equation.

There were variations in the growth patterns of both $M$. cephalus and $O$. niloticus examined across the period of study. Both species exhibited positive and negative allometric growth patterns but isometric growth was only observed in $M$. cephalus during the month of June while the only positive growth pattern for the same species was just in the following month of July. This study found the two fish species not to fulfill the cube law $(b<\&>3)$ however, M. cephalus seemed to comply with the cube law $(b=3.003)$ during the month of June only. During the month of June, this study found that Mugilids retained their body shape and specific gravity in view of isometric growth as suggested by Lagler (1952) and 
Wootton (1998) but the remaining period of the study had the Mugilids depart from isometric growth which according to Le Cren (1951) could be due to environmental factors or condition of the fish. The observed isometry in this study accords with the findings of Muchlisin et al. (2017) who also reported isometric growth with b-value of 3.04 for snapper (Lutjanus russellii). The coefficient of growth (b-values) obtained in this study corroborates the findings of Moslen and Uyovbukerhi (2017) in a study of four fish species from commercial landings in Port Harcourt with the following observations; Mugil sp. (2.2 - 3.2), Sardinella sp. (2.4 - 2.8), Tilapia sp (0.9 - 2.0) and Arius sp $(1.5-3.1)$. In another study of four Mugilids Zubia et al. (2014) observed that Liza melinoptera and Valamugil speigleri showed negative allometric growth $(\mathrm{b}<3.0)$, while M. cephalus and Liza macrolepis indicated positive allometric growth with $b$-values greater than ideal value $(b=3.0)$. Oribhabor et al. (2009) also reported isometric growth for Sarotherodon melanotheron in the Niger Delta which is at variance with the findings of this study. However, findings of this study also agrees with Khawar et al. (2015) who found significant relationship between length and weight in their studies of Mugil incilus. About $66.6 \%$ of the study period showed Oreochromis nilticus generally had higher growth coefficients (b-values) compared to M. cephalus obtained from the same environment. This implied that the two species examined did not have exactly the same growth pattern even though they were affected by similar environmental factors. In other words intra and inter specific growth pattern was observed in the two species studied due mainly to biological factors and individual fish condition and habit. The generally high $b$-values obtained in this study conforms with those of Wootton (1998) and Abowei (2010) in their respective studies and revealed that the present condition of M. cephalus and $O$. niloticus in the study area was more suitable for feeding and optimum growth of fish (Zubia et al., 2014). Oribhabor et al. (2011) in a study of different fish species in the Niger Delta also reported b-values $(0.97-5.67)$ and $R^{2}$ (0.22-0.99) within the range of the results observed in the current study. The coefficient of determination $\mathrm{R}^{2}$ values obtained in this study also corroborate that $(0.93)$ noticed by Shahabuddin, (2015) and those $(0.60-0.98)$ recorded by Christina et al. (2016) suggesting strong length weight relationships. The condition factor $(\mathrm{K})$ of a fish reflects physical and biological circumstances and fluctuations by interaction among feeding conditions, parasitic infections and physiological factors (Le Cren, 1951). Condition factor of the two species examined was almost the same suggesting very minimal intra and inter specific condition for the two fish species. The reason is that irrespective of the inter and intra species differences both species responded almost the same way to the environmental and ecological factors contributing greatly to the minimal difference between the condition factors of the two fish even when they are different species. The K-values obtained suggested that both fish species examined were in good condition during the study period. The result of this study agrees with the findings of the following studies; Khawar et al. $(2015$ who reported negative allometric growth $(b<3)$ and good condition for Muil incilus over a one year study, Moslen and Uyovbukerhi, (2017) who reported good condition $(\mathrm{K}=1.0$ - 1.06) of four fish species in Port Harcourt attributed to favourable ecological conditions for such commercially important fish species around Port Harcourt. Dan-Kishiya, (2013) found k-values of $1.06-2.02$ while Muchlisin et al. (2017) reported $(\mathrm{K}=2.49$ - 3.01) and Datta et al. (2013) reported that condition factor further indicates the changes in food reserves and therefore an indicator of the general fish condition.
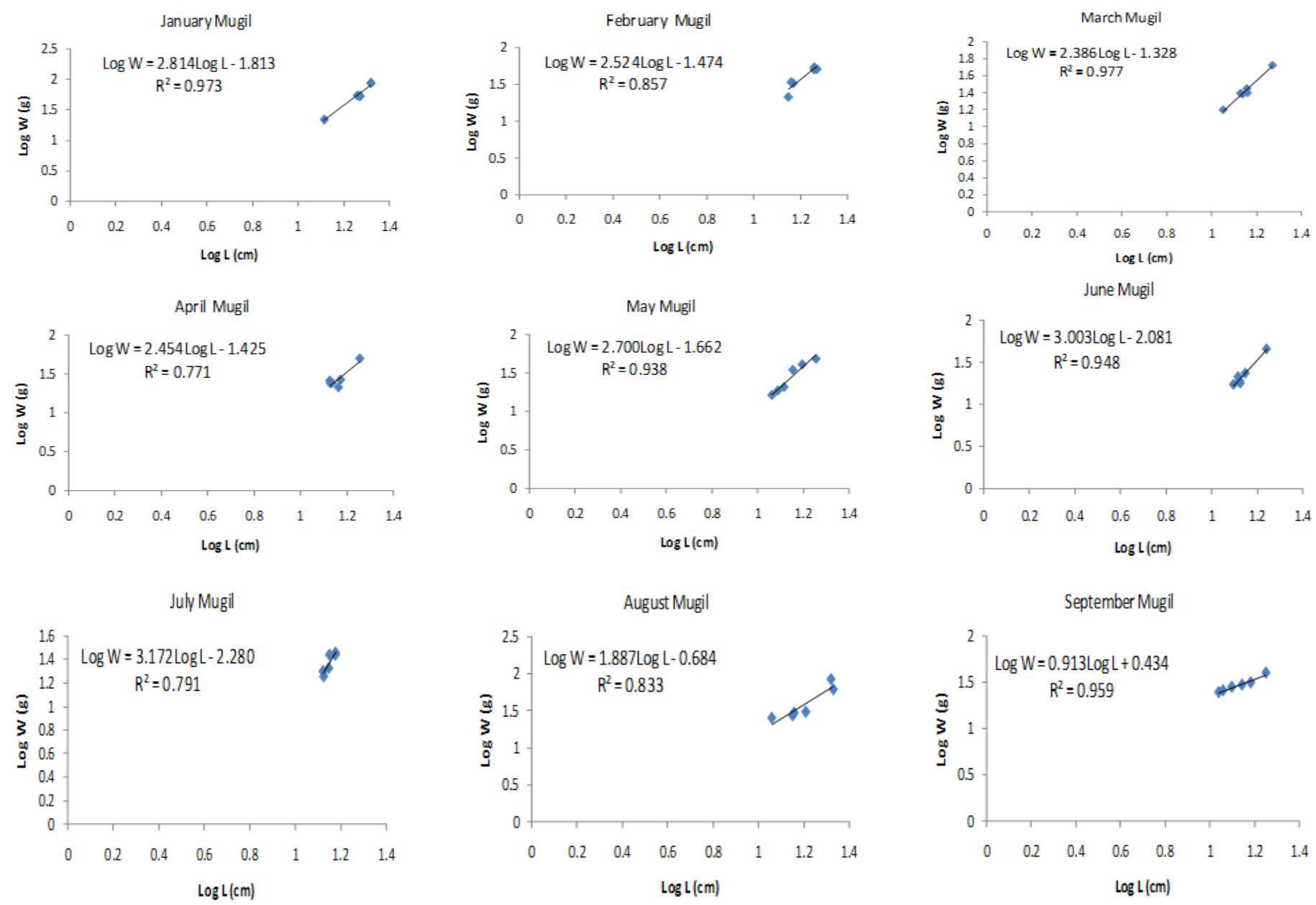
Figures 2. Contd.
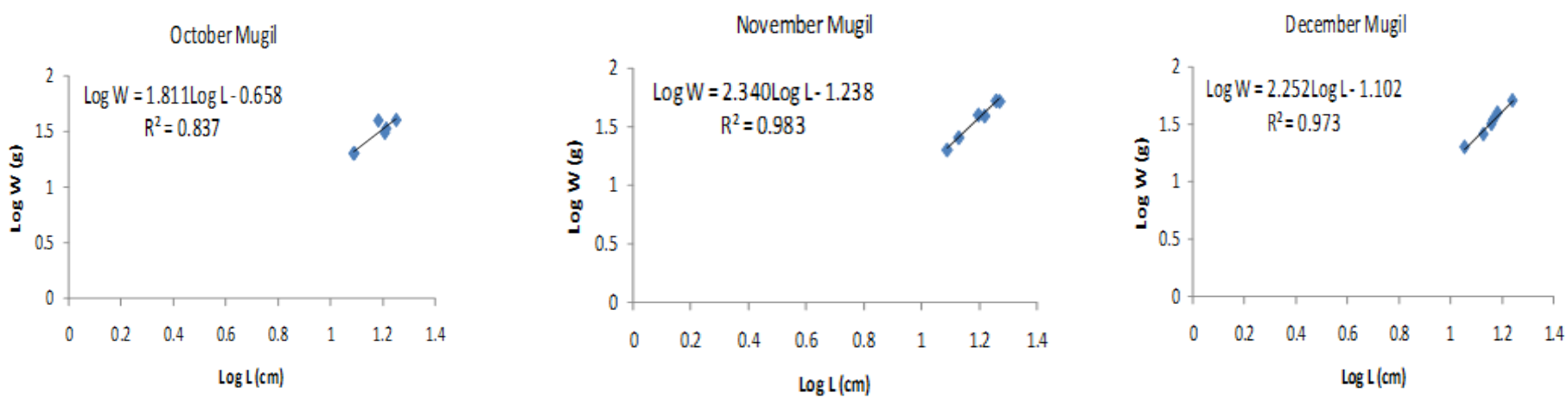

Figure 2. Scatter plots and regression equations for M. cephalus during the study periods.

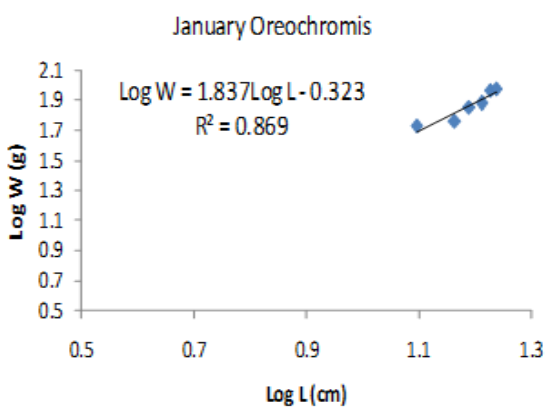

AprilOrechromis

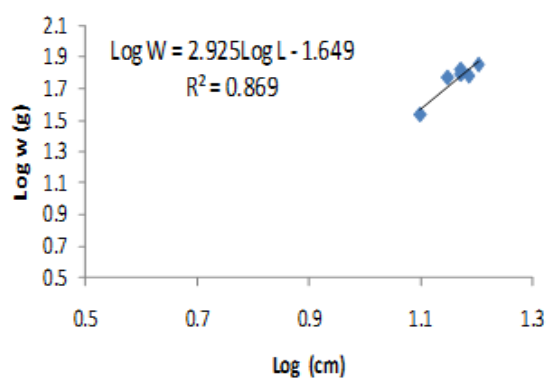

July Oreochromis

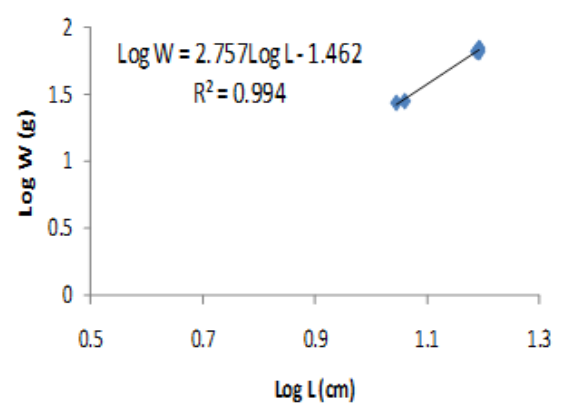

October Oreochromis

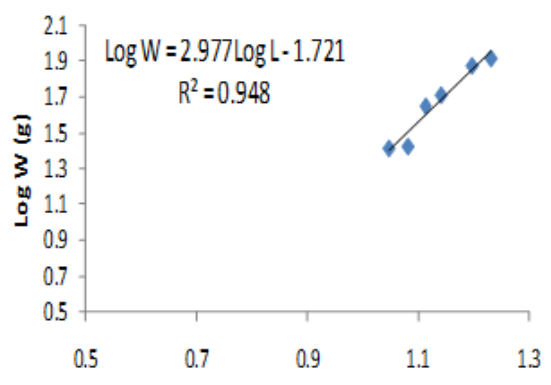

$\log L(\mathrm{~cm})$
February Orechromis

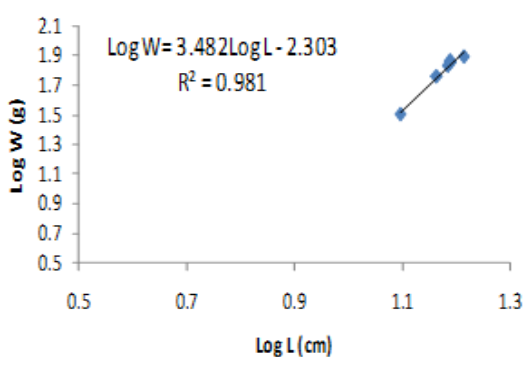

May Oreochromis

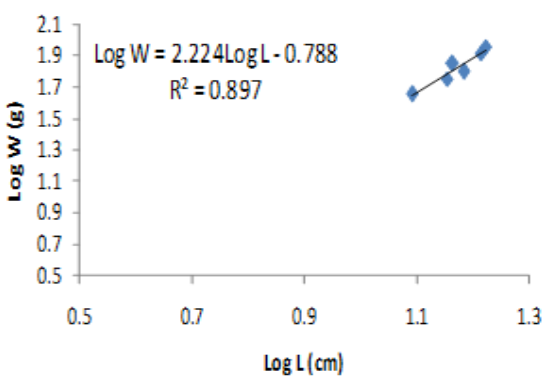

August Oreochromis

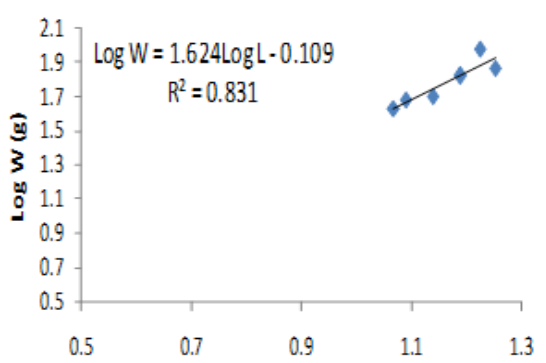

$\log L(\mathrm{~cm})$

November Oreochromis

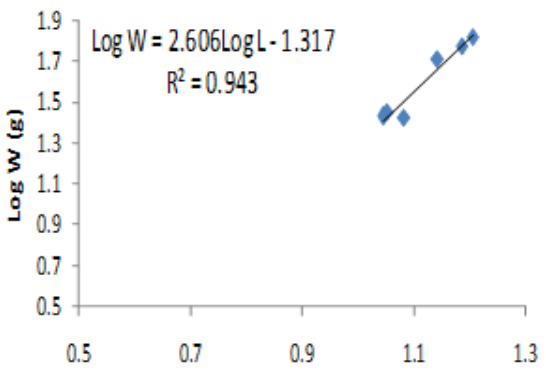

$\log 1(\mathrm{~cm})$

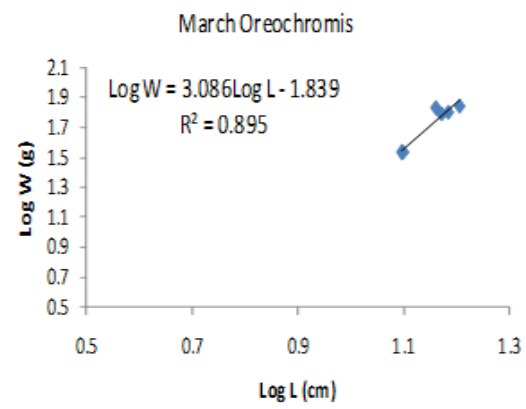

June Oreochromis

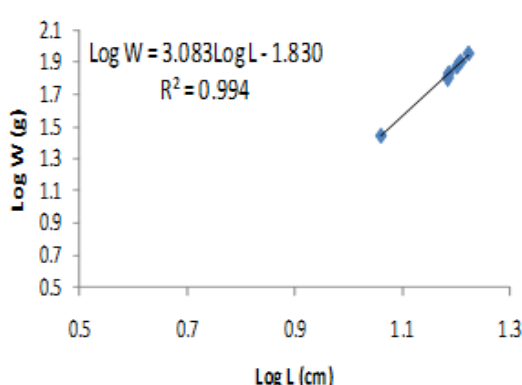

September Oreochromis

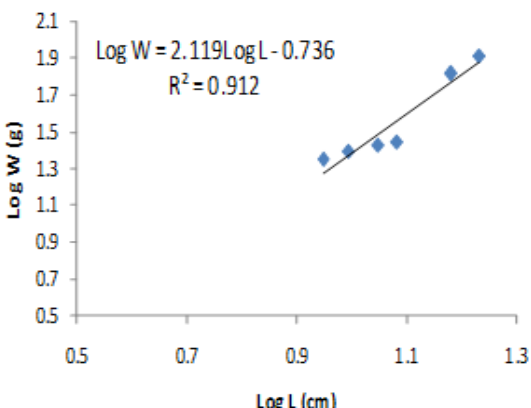

December Oreochromis

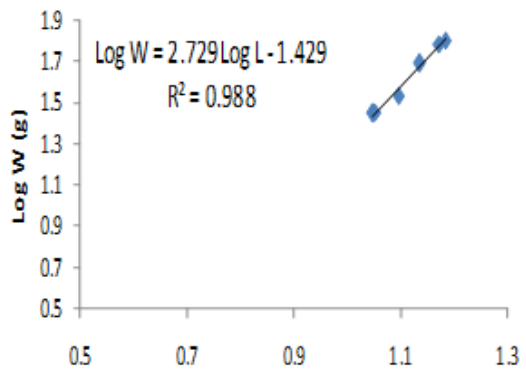

$\log L(\mathrm{~cm})$

Figure 3. Scatter plots and regression equations for $O$. niloticus during the study periods. 


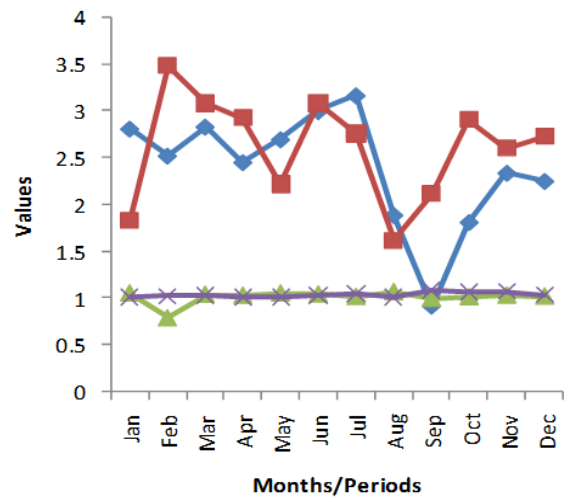

Figure 4. Temporal trends in the $b$-values and $K$-values of fish samples examined.

\section{Conclusions}

This study concluded that $M$. cephalus and $O$. niloticus observed over a period of one year in a tidal creek in the Niger Delta exhibited negative and positive allometric growth factors with strong length weight relationship. However, only $M$. cephalus showed isometric growth for only one month. Inter and intra specific LWR was obvious but inter and intra specific condition was very minimal due to biological, ecological and environmental factors prevailing in the study creek. The findings of this study also adds to the existing knowledge of biology of the these two species and serve as further guide to prospective aquaculture development in view of the high demand for such fish species of commercial and economic importance.

Open Access: This is open access article distributed under the terms of the Creative Commons Attribution License, which permits unrestricted use, distribution, and reproduction in any medium, provided the original author(s) and the source are credited.

\section{REFERENCES}

Abowei, J.F.N. (2010). The condition factor, length-weight relationship and abundance of Ilisha africana (Block, 1795) from Nkoro River Niger Delta, Nigeria. Advance Journal of Food Science and Technology, 2: 6-11.

Ali, M., Salam, A. and Iqbal F. (2000). Weight-length and condition factor of wild Channa punctata from Multan. Punjab University Journal of Zoology, 15:183-189.

Anderson, R.O. and Gutreuter, S.S. (1985). Length-weight relationship and associated indices. American Fisheries Society, 283300.

Bolger, T. and Connolly, P.L. (1989). The suitable of suitable indices for the measurement analysis of fish condition. Journal of Fish Biology, 34:171-182.

Christina, A.P., Anni, J.A.M.D. and Jeyaseeli, A. (2016). Lengthweight relationship and condition factor of freshwater fish Tilapia mossambica. Journal of Bio Innovation, 5(5): 758-763.

Dan-Kishiya, A.S. (2013). Length-weight relationship and condition factor of five fish species from a tropical water supply reservoir in Abuja, Nigeria. American Journal of Research Communication, 1(9): 175-187.

Ighwela, K.A., Ahmed, A.B. and Abol-Munafi, A.B. (2011). Condition factor as an indicator of growth and feeding intensity of Nile Tilapia fingerlings (Oreochromis niloticus) feed on different levels of maltose American-Eurasian. Journal of Agriculture and Environmental Science, 11 (4): 559-563

Khallaf, E., Galal, M. and Athuman, M. (2003). The biology of Oreochromis niloticus in a polluted canal. Ecotoxicology, $12: 405-416$

Khawar, M., Kalsoom, R. Masood, Z., Hasan, Z., Iqba, F., Razzaq, W. and Hameed-Ur-Rehman (2015). Length-weight relationship, condition and relative condition parameters of Mugilinci-
Table 1. ANOVA summary with $\mathrm{F}$ and $\mathrm{P}$-values.

\begin{tabular}{lcc}
\hline & F-values & P-values \\
\hline M. cephalus & & \\
Length & 1.79 & 0.075 \\
Weight & 2.72 & $0.007^{*}$ \\
O. niloticus & & \\
Length & 1.4 & 0.197 \\
Weight & 1.95 & $0.05^{*}$ \\
\hline
\end{tabular}

* Significant

lus (Mugilidae: Mugiliformes) collected from the River Indus of district Sukkur, Pakistan. Biological Forum - An International Journal, 7(1): 793-799.

Lagler, K.F. (1952). Fresh water fishery biology. WC Brown Company, Dubuque, Iowa, 360. 21.

Le Cren, E.D. (1951). The length-weight relationship and seasonal cycle in gonad weight and condition in the perch (Perca fluviatilis). Journal of Animal Ecology, 20: 201-219.

Lima-Junior, S.E., Cardone, I.B. and Goite, R. (2002). Determination of a method for calculation of Allometric Condition Factor of fish. Acta Scientiarum, 24:397- 400

Lizama, M. de los A.P. and Ambrósio, A.M. (2002). Condition factor in nine species of fish of the characidae family in the upper Parana River floodplain, Brazil. Brazilian Journal of Biology, 62(1): 113-124.

Miebaka, M. and Uyovbukerhi, E.G. (2017). Length-weight relationship and condition factor of some fish from commercial landings around Port Harcourt, Nigeria. Journal of Nigeria Environmental Society, 11(1): $141-147$.

Migiro, K.E., Ogello, EO. and Munguti, J.M. (2014). The lengthweight relationship and condition factor of Nile Tilapia (Oreochromis niloticus L.) Broodstock at Kegati Aquaculture Research Station, Kisii, Kenya. International Journal of Advanced Research, 2(5):777-782.

Mortuza, M.G. and Al-Misned F. (2013). Length-weight relationships, condition factor and sex-ratio of Nile tilapia, Oreochromis niloticus in Wadi Hanifah, Riyadh, Saudi Arabia. World Journal of Zoology, 1:106-109.

Muchlisin, Z.A., Fransiska, V., Muhammadar, A.A., Fauzi, M. and Batubara1, A.S. (2017). Length-weight relationships and condition factors of the three dominant species of marine fishes caught by traditional Beach Trawl in Ulelhee Bay, Banda Aceh City, Indonesia. Croatian Journal of Fisheries, 75:104-112

Nehemia, A., Maganira, J.D. and Rumisha, C. (2012). Length-weight relationship and condition factor of tilapia species grown in marine and fresh water ponds. Agriculture and Biology Journal of North America, 3:117-124.

Olurin, K.B. and Aderibigbe, O.A. (2006). Length-weight relationship and condition factor of pond reared juvenile Oreochromis niloticus. Journal of Zoology, 1:82-85.

Oni S.K., Olayemi J.Y. and Adegboye J.D. (1983). Comparative physiology of three ecologically distinct freshwater fishes, Alestes nurse Ruppell, Synodontis schall Broch \& Schneider and Tilapia zillii Gervais. Journal of Fish Biology, 22: 105-109; DOI 10.1111/j.1095-8649.1983.tb04730.x

Oribhabor, B.J., Mokayi, P.K. and Akinrotimi, A.O. (2009). Lengthweight relationship of Sarotherodon melanotheron (RUPPELL, 1852) and Tilapia guinensis (GUNTHER, 1862) (PERCIFORMES: Cichlidae) in a Niger Delta mangrove creek, Nigeria. Nigerian Journal of Agriculture, Food and Environment, 5(2-4): 1-4.

Oribhabor, B.J., Ogbeibu, A.E. and Udo, M.T (2011). The lengthweight relationships of brackish water/marine fish species assemblage in a Niger Delta Mangrove Creek, Nigeria. Current Research Journal of Biological Sciences, 3(6): 616-621.

Pauly, D. (1993). Linear regressions in fisheries research. Journal of 
the Fisheries Research Board of Canada, 30:409-434.

Pauly, D. (1983). Some simple methods for the assessment of tropical fish stock. FAO Fisheries Technical paper, No. 234, 52 .

Shahabuddin, A.M., Khan, M.N.D., Saha, D., Ayna, E., Wonkwon, K., Murray, W.W., Yoshimatsu, T. and Araki T. (2015). Length -weight relationship and condition factor of juvenile Nile Tilapia Oreochromis niloticus (Linnaeus 1758) Fed Diets with Pyropia spheroplasts in closed recirculating system. Asian Fisheries Science, 28:117-129

Silva, T.S.d.C., Santos, L.D.d, Silva,L.C.R.d., Michelato, M., Furuya, V.R.B. and Furuya, W.M. (2015). Length-weight relationship and prediction equations of body composition for growing-finishing cage-farmed Nile tilapia. Revista Brasileira de Zootecnia, 44(4):133-137.

Weatherly, A.H. and Gill, H.S. (1987): The biology of fish growth, London, academic Press. 433-443.

Wootton, R.J. (1998). Ecology of teleost fishes. 2nd edition. Chapman and Hall. Upper Saddle River, New Jersey, USA. 24.

Zubia, M., Rehana, Y., Muhammad, S.H., Omer, M.T.,Lakht-e-Zehra and Adeyemi, S.O. (2014). Length-weight relationship, condition and relative condition factor of four Mugilid Species (Family mugildae) from the Karachi Coast of Pakistan. Journal of Coastal Development, 17(385): 1-6. 